\title{
An Assessment of Labour Productivity Influencing Factors in the Construction Industry: A Case study of Zaria, Nigeria
}

\author{
T. Adagba ${ }^{1 *}$, JO Ati $^{2}$, AM Ibrahim ${ }^{3}$ \\ ${ }^{* 1}$ Federal University Dutsin-Ma, Department of Civil Engineering, Nigeria, tadagba@fudutsinma.edu.ng \\ ${ }^{2}$ Ahmadu Bello University, Department of Building, Nigeria, joshuaati97@gmail.com \\ ${ }^{3}$ Ahmadu Bello University, Department of Building, Nigeria, aliyuibrahimmakarfi@yahoo.co.uk
}

\begin{abstract}
In this research, factors influencing construction labour productivity in Zaria, Nigeria was assessed. The aim of the research was to identify these factors and rank them according to their severity. This information will aid site managers and the construction professionals on decisions to take in-order to limit these controlling factors thereby leading to an improved level of efficiency in labour force, increase product labour productivity and reduce cost and time over runs on construction projects. The research adopted a quantitative research approach with the use of questionnaires as an instrument for data collection from site managers at construction sites in Zaria. The Questionnaire sought to assess the perception of site managers on factors affecting construction labour productivity. Thirty-Nine out of the Forty-One factors researched indicated high severity with the RII ranging between $0.60 \leq$ RII $<0.80$. The research revealed that external forces tend to affect construction labour productivity more than site factors and human labour factors. This can be attributed to the fact that the site engineers can control site factors and human labour factors while the external factors cannot be really controlled by the site engineers. The survey also revealed that rain, conflict with project stakeholders, skill of labour, and financial crisis had a very high severity in affecting construction labour productivity on the construction sites.
\end{abstract}

Keywords: Construction Labour Productivity, Perception, Severity, Relative Importance Index (RII), Construction Industry, Nigeria.

Received: July 16, 2021 / Accepted: August 18, 2021 / Online: August 19, 2021

\section{INTRODUCTION}

The Nigerian construction industry is be-devilled with issues ranging from corruption during the award of contracts, to the total neglect of projects due to cash flow problems. As a result, construction workers have been subjected to a work environment which does not encourage high levels of efficiency. The non-payment or delay of wages/salaries, the disruption of work due to lack of materials or tools, and the resulting loss of morale have led to an exodus of traditional craftsmen from the industry [1]. Attar, et al. [2] noted that construction is a key sector of the national economy for countries all around the world, as traditionally it takes up a big portion in the nation's total employment and its significant contribution to a nation's revenue as a whole. One of the main factors as noted by Khaled and Remon [3] influencing the construction industry growth is productivity and it is mainly associated with the labour performance. According to Bekr [4],
Construction Labour productivity can be said to be the units of work produced or placed in an hour.

At low levels, CLP can be dangerous causing social conflicts to a Nation's economy $[5,6]$. Identification of these factors affecting productivity levels is important, as it will aid site handlers in tackling such problems thereby reducing time and cost overruns $[7,8]$. It will also help to improve labour productivity at the sites [9]. The construction industry's productivity is vital considering the enormous effect it has on a Nation's GDP [10]. An improved productivity means a rise in GDP.

This research identifies various labour productivity factors, analyse them statistically, assess the difference in perception between the various professionals in construction and finally looks at its findings in line with other previous studies. 


\section{LITERATURE REVIEW}

The construction industry in Nigeria is a very dynamic one. Over the last few years, impressive numbers have been recorded. The industry is heavily dependent on government expenditure, that's why the industry is growing at the same time with government revenue [11]. Jobs have been created with a great potential of expansion due to the labour intensiveness of construction industry and the ever increasing demand for services in the sector [12].

\section{A. Concept and Characteristics of Labour}

Abdullahi [13] defined labour as a term referring to all physical and mental work undertaken for monetary rewards. Amadeo [14] defined labour as the quantity of physical, mental and social effort used to produce goods and services. He classified labour into that based on skill level and that based on relationship with the employer. Based on skill level, labour is classified into Unskilled, semi-skilled and skilled labour. While classifying labour based on relationship is grouped into wage labour and contract labour.

According to Smriti [15] labour is perishable, it cannot be separated from the labourer, it is inelastic in supply, has differences in its efficiency and estimating it's production cost is difficult.

Kale and Doguwa [16] describe total labour force as comprising of the working age population that are either employed or unemployed. These are individuals within the ages 15 and older (64 years in the case of Nigeria).

\section{B. Labour Productivity}

Productivity refers to the output generated from a system and the input used to create output. It is expressed as:

$$
\text { Labour Productivity }=\frac{\text { output }}{\text { Work hour }}
$$$$
\text { or }
$$$$
\text { Labour Productivity }=\frac{\text { output }}{\text { Labour cost }}
$$

\section{1) Average Labour Productivity (ALP)}

Average Labour Productivity ALP looks at the impact of one factor input (labour). Its main limitation is that as a single factor measure it cannot be used for analysis of total productivity performance [17]. According to Merrow, et al. [18], there are three approaches to measuring average labour productivity. The economist approach, the construction manager's approach and the project approach.

\section{2) Total Factor Productivity (TFP)}

According to [19], Total Factor Productivity (TFP) is the most widely used measure of productivity. Total factor productivity is the ratio of aggregated inputs to aggregated outputs Kendrick [20]. It's main disadvantage however, is that it allows little room for differentiating the influence of factors that can be controlled internally from those that are imposed externally.

\section{Benefits of Productivity Management}

According to Edosomwan [21] management of productivity enables the consumer to pay low prices for goods and services, ensure the effective utilisation of resources. Other benefits includes providing the basis for higher incomes for employees, providing an organisation with the strength to deal with internal operating weakness and external competition, enable an organisation to be more profitable and enable the public realise greater social benefits.

Other benefits as outlined by Eilon et al (1976) include:

- For strategic purposes: to compare the performance of the company with that of its competitors of related firms,

- For tactical purposes: to regulate the performance of the firm

- For planning purposes: as the basis for considering alternative adjustments over future periods.

- For other management purposes: such as collective bargaining with trade unions.

\section{Factors affecting Construction Labour Productivity in} Nigeria.

Odesola, et al. [22] in a research carried out in Bayelsa, Nigeria, assessed using questionnaire identified 18 factors that ranked according to their importance. These were, specification and standardisation as the most important while stoppage due to disputes was the least important. Edwin and Calistus [23] carried out a survey using questionnaires in carpentry and steel fixing in North-central Nigeria. A total of 21 factors were identified with design shape and size as the most important while labour personal problems was ranked as the least important. Odesola [24] carried out a research in Cross River, Nigeria. Thirty-one (31) factors were identified in the research. Material management was ranked the most important while lack of big picture view on behalf of the crafts was ranked the least. Olomolaiye, et al. [1] were among the first researchers on productivity in Nigeria. They carried out an assessment using activity sampling and questionnaire surveys. Eight (8) problems influencing craftsmen's productivity were identified in the research with lack of materials been ranked as the most important and changing of crew members was ranked the least important. Odesola and Idoro [25] carried out a study which covered the six geographical states in Nigeria's south-south geopolitical zone structured questionnaires. Fifteen (15) factors were identified in the research and ranked according to their level of importance. Craft workers' pride was ranked the most important and lack of competition was ranked the least.

\section{F. Factors Influencing Construction Labour Productivity in other Countries}

Khaled and Remon [3] in a research carried out in Egypt assessed thirty (30) factors which were ranked according to their level of importance. Enshassi, et al. [26] in a research carried in the Gaza strip assessed Forty-five (45) factors with the use of questionnaires. The factor ranked as the most 
important was material shortages while the least important was noise. Thomas and Sudhakumar [27] carried out a survey with the use of questionnaires in India. Forty-three (43) factors were assessed. Unavailability of material on time at workplace was ranked the most important while excessive overtime was ranked the least. Jarkas and Bitar [28] assessed Forty-five (45) factors in a research in Kuwait. Clarity of technical specifications was the most important while rain was ranked the least important. Makulsawatudom and Emsley [29] in Thailand assessed Twenty-three (23) factors. The most important factor was lack of material while work shift was ranked the least. Hickson and Ellis [30] in a study in Trinidad and Tobago assessed forty-two (42) factors in their research. The most important factor was lack of labour supervision, unsuitability of storage location was ranked the least. Gundecha [31] used questionnaires sent by email to various professionals. Forty (40) factors were assessed in the study. The most important factor was lack of required construction material, while personal problems was ranked the least important.

\section{RESEARCH METHOD}

The quantitative approach was used. Method of data collection was literature review and structured questionnaire. The population frame of this research are site managers on Sixty-nine (69) active construction sites within Zaria.

\section{1) Sampling method}

A non-probability sampling method known as purposive sampling was used for the research. Kish's Formula was used for calculating sample size

Where $\mathrm{n}=$ Sample size

$$
n=\frac{n 1}{1+\left(\frac{n 1}{N}\right)}
$$

$$
n 1=\frac{s^{2}}{v^{2}}
$$

$\mathrm{N}=$ Population size

$\mathrm{V}=$ Standard error of sampling distribution $=0.05$

$S 2=P(1-P)=(0.5)(0.5)=0.25$

$\mathrm{P}=$ the proportion of standard deviation in the population element (total error $=0.1$ at $95 \%$ confidence level).

$$
\begin{aligned}
& n 1=\frac{0.5^{2}}{0.05^{2}} \\
& n 1=\frac{0.25}{0.0025}=100
\end{aligned}
$$

Substituting in equation 3.1 ;

$$
\begin{aligned}
& n=\frac{100}{1+\left(\frac{100}{69}\right)} \\
& n=41
\end{aligned}
$$

\section{2) Sampling method}

Statistical Package for Social Sciences (SPSS) was used to get frequency table which in turn was used to analyse the respondents' general information. The factors affecting construction was analysed using frequency tables and a Kruskal Wallis Test was done to determine the difference in perception between the various professions. Relative importance index (RII) and Item Mean was used to rank the factors according to their significance. The RII and Item Mean was done using a programmed Microsoft Excel Sheet and the formula used was

$$
\begin{gathered}
R I I=\frac{5 n_{5}+4 n_{4}+3 n_{3}+2 n_{2}+1 n_{1}}{5\left[n_{5}+n_{4}+n_{3}+n_{2}+n_{1}\right]} \\
\text { Mean }=\frac{5 n_{5}+4 n_{4}+3 n_{3}+2 n_{2}+1 n_{1}}{\text { Total respondents }}
\end{gathered}
$$

Where $n_{5}=$ Frequency of "Strongly Agree" response $n_{4}=$ Frequency of "Agree" response

$n_{3}=$ Frequency of "Neutral" response

$n_{2}=$ Frequency of "Disagree response

$n_{1}=$ Frequency of "Strongly Disagree" response

An RII $<0.60$ indicates low severity of the factor;

$0.60 \leq \mathrm{RII}<0.80$ indicates high severity,

An $\mathrm{RII} \geq 0.80$ indicates a very high severity of the factor.

Factors used for analysis were divided into three groups as adopted by Hickson and Ellis [30]. Each factor was given a serial number according to the group it belongs. Table 3.1, Table 3.2 and Table 3.3 shows the factors in their various groupings with their serial number.

\begin{tabular}{cl} 
TABLE 3.1: SITE FACTORS \\
\hline A & Site Factors \\
\hline A1 & Delay in responding to request for information \\
A2 & Rework \\
A3 & Amount of variation/change of orders during execution \\
A4 & Clarity of technical specification \\
A5 & Level of co-ordination among design disciplines i.e. Architects, \\
& Engineers, etc. \\
A6 & Compatibility and consistency among contract document \\
A7 & Strict inspection by the engineer \\
A8 & Complexity of the design and project \\
A9 & Restricted access on site \\
A10 & Inspection delay by the engineer \\
A11 & Confinement of working space \\
A12 & Site layout \\
A13 & Mobilization/Demobilization \\
A14 & Hazardous Work Area \\
A15 & Excessive labour/Over-manning \\
A16 & Lack of places for eating and relaxation \\
A17 & Non provision of transport means for workers \\
\hline
\end{tabular}

\begin{tabular}{cl} 
TABLE 3.2: HUMAN LABOUR FACTORS \\
\hline B & Human Labour Factors \\
\hline B1 & Shortage of experienced labour \\
B2 & Skill of labour \\
B3 & Lack of competition /motivation of labour \\
B4 & Physical fatigue \\
B5 & Craft workers' pride in their work \\
B6 & Labour disloyalty \\
B7 & Labour dissatisfaction \\
B8 & Increase of labourer's age \\
B9 & Drug abuse and alcoholism \\
B10 & Labour absenteeism \\
B11 & Poor health of workers \\
B12 & Labour personal problems \\
B13 & Poor economic condition of workers \\
B14 & Literacy level \\
\hline
\end{tabular}


TABLE 3.3: EXTERNAL FACTORS

\begin{tabular}{ll}
\hline C & External Factors \\
\hline C1 & Rain \\
C2 & High Temperature \\
C3 & Weather and Season Changes \\
C4 & Government polices \\
C5 & Cultural conditions and customs of the community at the \\
& project site \\
C6 & Religious holidays/other holidays \\
C7 & Rise in fuel prices \\
C8 & Environmental pollution \\
C9 & Conflict with project stakeholders \\
C10 & Financial Crisis \\
\hline
\end{tabular}

IV. DATA PRESENTATION AND DISCUSSION TABLE 4.1 RETURN RATE OF QUESTIONNAIRE

\begin{tabular}{lll}
\hline & Frequency & Percentages \\
\hline Not-Returned & 26 & 39 \\
Returned & 41 & 61 \\
Distributed & 67 & 100 \\
\hline TABLE 4.2: RESPONDENTS' YEARS OF EXPERIENCE \\
\hline Years & Frequency & Percent \\
\hline Less than 5 & 6 & 14.6 \\
5-10 & 18 & 43.9 \\
$11-15$ & 10 & 24.4 \\
More than 15 & 7 & 17.1 \\
Total & 41 & 100.0 \\
\hline
\end{tabular}

TABLE 4.3: RESPONDENTS' QUALIFICATION

\begin{tabular}{lll}
\hline & Frequency & Percent \\
\hline Diploma & 3 & 7.3 \\
HND & 9 & 22.0 \\
BSc/BEng & 13 & 31.7 \\
MSc & 10 & 24.4 \\
PhD & 1 & 2.4 \\
Others & 5 & 12.2 \\
Total & 41 & 100.0 \\
\hline
\end{tabular}

TABLE 4.4 PROFESSION IN THE CONSTRUCTION INDUSTRY

\begin{tabular}{lll}
\hline & Frequency & Percent \\
\hline Architect & 3 & 7.3 \\
Builder & 11 & 26.8 \\
Quantity Surveyor & 5 & 12.2 \\
Engineer & 14 & 34.1 \\
Project Manager & 1 & 2.4 \\
Craftsman & 2 & 4.9 \\
Others & 5 & 12.2 \\
Total & 41 & 100.0 \\
\hline
\end{tabular}

TABLE 4.5 SIZE OF THE ORGANIZATION

\begin{tabular}{lll}
\hline & Frequency & Percent \\
\hline Small & 8 & 19.5 \\
Medium & 19 & 46.3 \\
Large & 14 & 34.1 \\
Total & 41 & 100.0 \\
\hline
\end{tabular}

Table 4.1 shows the return rate of response. Sixty-seven questionnaires were distributed. Forty-one questionnaires were retuned while Twenty-six were not, indicating a return rate of $61 \%$.

Table 4.2 shows the years of respondent's experience. More than $50 \%$ of the respondents' had at least 5 years of professional experience.

Table 4.3 shows that more than half of the respondents have a qualification of B.Sc/B.Eng or above.

Table 4.4 show that Engineers and Builders made above half of the respondents while table 4.5 shows that the medium sized companies had the highest percentage of respondents.

The characteristics listed above indicates that the respondents possess the requisite knowledge and experience to provide reliable information on which reliable conclusions can be made. Table 4.6, 4.7 and 4.8 show the ranking of site factors, human labour factors and external factors while table 4.9 show the overall ranking of all the factors. It shows rain, conflict with project stakeholders, skill of labour, financial crisis and government policies the topmost severity. 
Adagba et al. / Journal of Civil Engineering Frontiers Vol. 02, No. 02, pp. 26 -37, (2021)

Table 4.6: Ranking of Site Factors

\begin{tabular}{|c|c|c|c|c|c|}
\hline $\mathbf{S} / \mathbf{N}$ & Site Factors & RII & Mean & Rank & Grank \\
\hline A14 & Hazardous Work Area & 0.790 & 3.950 & 06 & 01 \\
\hline A3 & Amount of variation/change of orders during execution & 0.766 & 3.829 & 08 & 02 \\
\hline A5 & Level of co-ordination among design disciplines i.e. Architects, Engineers, etc. & 0.756 & 3.780 & 10 & 03 \\
\hline A6 & Compatibility and consistency among contract document & 0.756 & 3.780 & 11 & 04 \\
\hline A4 & Clarity of technical specification & 0.714 & 3.568 & 17 & 05 \\
\hline A13 & Mobilization/Demobilization & 0.713 & 3.564 & 18 & 06 \\
\hline A2 & Rework & 0.705 & 3.525 & 20 & 07 \\
\hline $\mathrm{A} 1$ & Delay in responding to request for information & 0.695 & 3.475 & 21 & 08 \\
\hline A8 & Complexity of the design and project & 0.693 & 3.463 & 22 & 09 \\
\hline $\mathrm{A} 12$ & Site layout & 0.690 & 3.450 & 23 & 10 \\
\hline A7 & Strict inspection by the engineer & 0.663 & 3.317 & 26 & 11 \\
\hline A 10 & Inspection delay by the engineer & 0.663 & 3.317 & 27 & 12 \\
\hline A9 & Restricted access on site & 0.659 & 3.293 & 30 & 13 \\
\hline A11 & Confinement of working space & 0.655 & 3.275 & 31 & 14 \\
\hline A17 & Non provision of transport means for workers & 0.652 & 3.261 & 32 & 15 \\
\hline A15 & Excessive labour/Over-manning & 0.610 & 3.051 & 37 & 16 \\
\hline A16 & Lack of places for eating and relaxation & 0.590 & 2.951 & 40 & 17 \\
\hline
\end{tabular}

Table 4.7: Ranking of Human Labour Factors

\begin{tabular}{|c|c|c|c|c|c|}
\hline $\mathbf{S} / \mathbf{N}$ & Human Labour factors & RII & Mean & Rank & Grank \\
\hline $\mathrm{B} 2$ & Skill of labour & 0.800 & 4.000 & 03 & 01 \\
\hline B1 & Shortage of experienced labour & 0.765 & 3.825 & 09 & 02 \\
\hline B13 & Poor economic condition of workers & 0.749 & 3.744 & 12 & 03 \\
\hline B3 & Lack of competition /motivation of labour & 0.740 & 3.700 & 13 & 04 \\
\hline B4 & Physical fatigue & 0.740 & 3.700 & 14 & 05 \\
\hline B11 & Poor health of workers & 0.718 & 3.590 & 16 & 06 \\
\hline B14 & Literacy level & 0.708 & 3.542 & 19 & 07 \\
\hline B7 & Labour dissatisfaction & 0.662 & 3.308 & 28 & 08 \\
\hline $\mathrm{B} 10$ & Labour absenteeism & 0.662 & 3.308 & 29 & 09 \\
\hline B6 & Labour disloyalty & 0.651 & 3.256 & 33 & 10 \\
\hline B9 & Drug abuse and alcoholism & 0.631 & 3.154 & 36 & 11 \\
\hline B12 & Labour personal problems & 0.605 & 3.027 & 38 & 12 \\
\hline B5 & Craft workers' pride in their work & 0.605 & 3.026 & 39 & 13 \\
\hline B8 & Increase of labourer's age & 0.537 & 2.684 & 41 & 14 \\
\hline
\end{tabular}

Table 4.8: Ranking of External Factors

\begin{tabular}{|c|c|c|c|c|c|}
\hline & External Factors & RII & Mean & Rank & Grank \\
\hline $\mathrm{C} 1$ & Rain & 0.840 & 4.200 & 01 & 01 \\
\hline C9 & Conflict with project stakeholders & 0.810 & 4.050 & 02 & 02 \\
\hline $\mathrm{C} 10$ & Financial Crisis & 0.800 & 4.000 & 04 & 03 \\
\hline $\mathrm{C} 4$ & Government polices & 0.795 & 3.975 & 05 & 04 \\
\hline $\mathrm{C} 5$ & $\begin{array}{l}\text { Cultural conditions and customs of the community at the } \\
\text { project site }\end{array}$ & 0.770 & 3.850 & 07 & 05 \\
\hline $\mathrm{C} 8$ & Environmental pollution & 0.735 & 3.675 & 15 & 06 \\
\hline $\mathrm{C} 2$ & High Temperature & 0.685 & 3.425 & 24 & 07 \\
\hline $\mathrm{C} 3$ & Weather and Season Changes & 0.685 & 3.425 & 25 & 08 \\
\hline $\mathrm{C} 6$ & Religious holidays/other holidays & 0.650 & 3.250 & 34 & 09 \\
\hline $\mathrm{C} 7$ & Rise in fuel prices & 0.645 & 3.225 & 35 & 10 \\
\hline
\end{tabular}




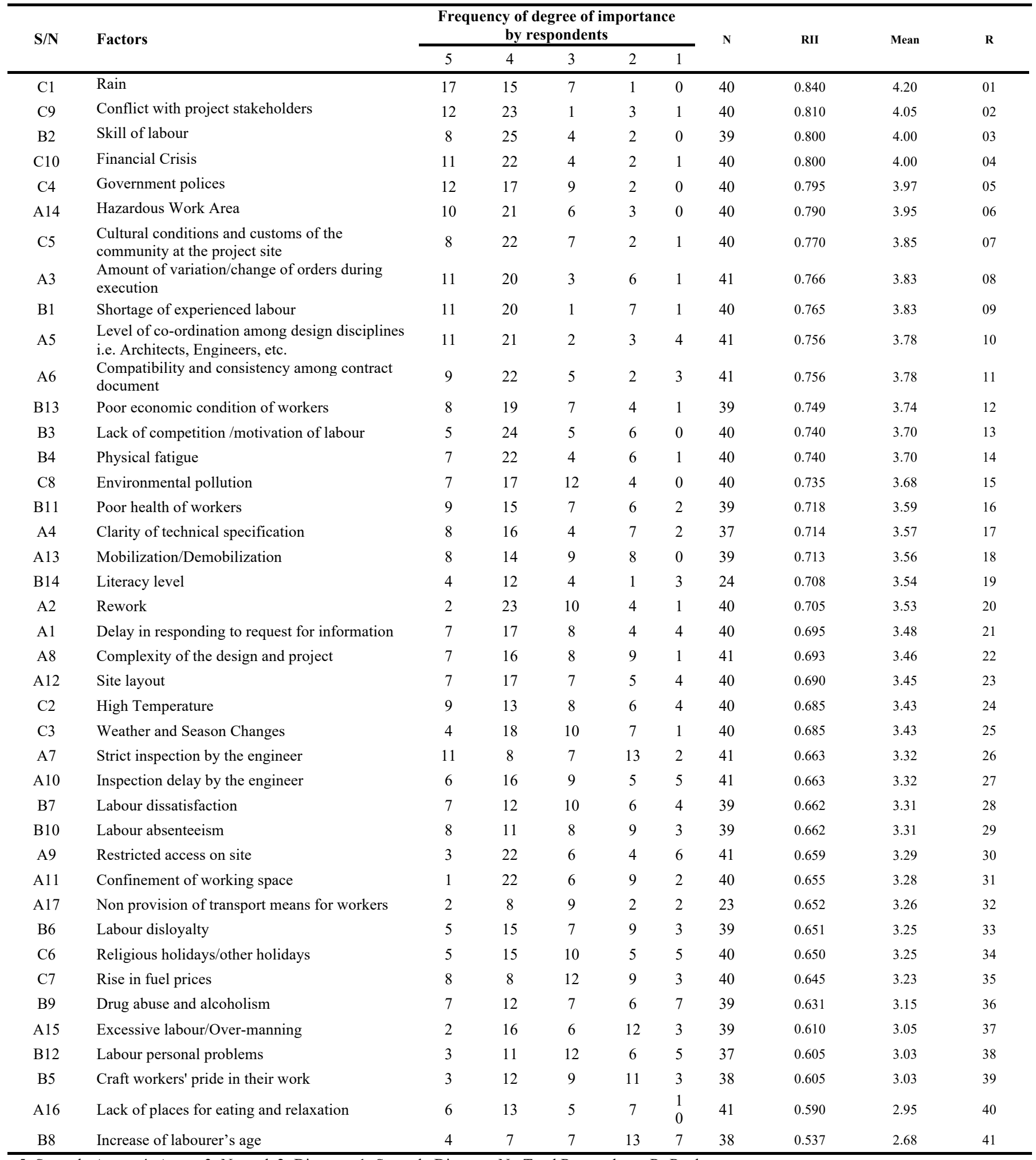

5=Strongly Agree, 4=Agree, 3=Neutral, 2=Disagree, 1=Strongly Disagree, N= Total Respondents, R=Rank 
Fig. 4.1: Cluster diagram showing the Relative Importance Index (RII) of the Construction Industry Professionals (Architects, Builders, Engineers \& Quantity Surveyors)

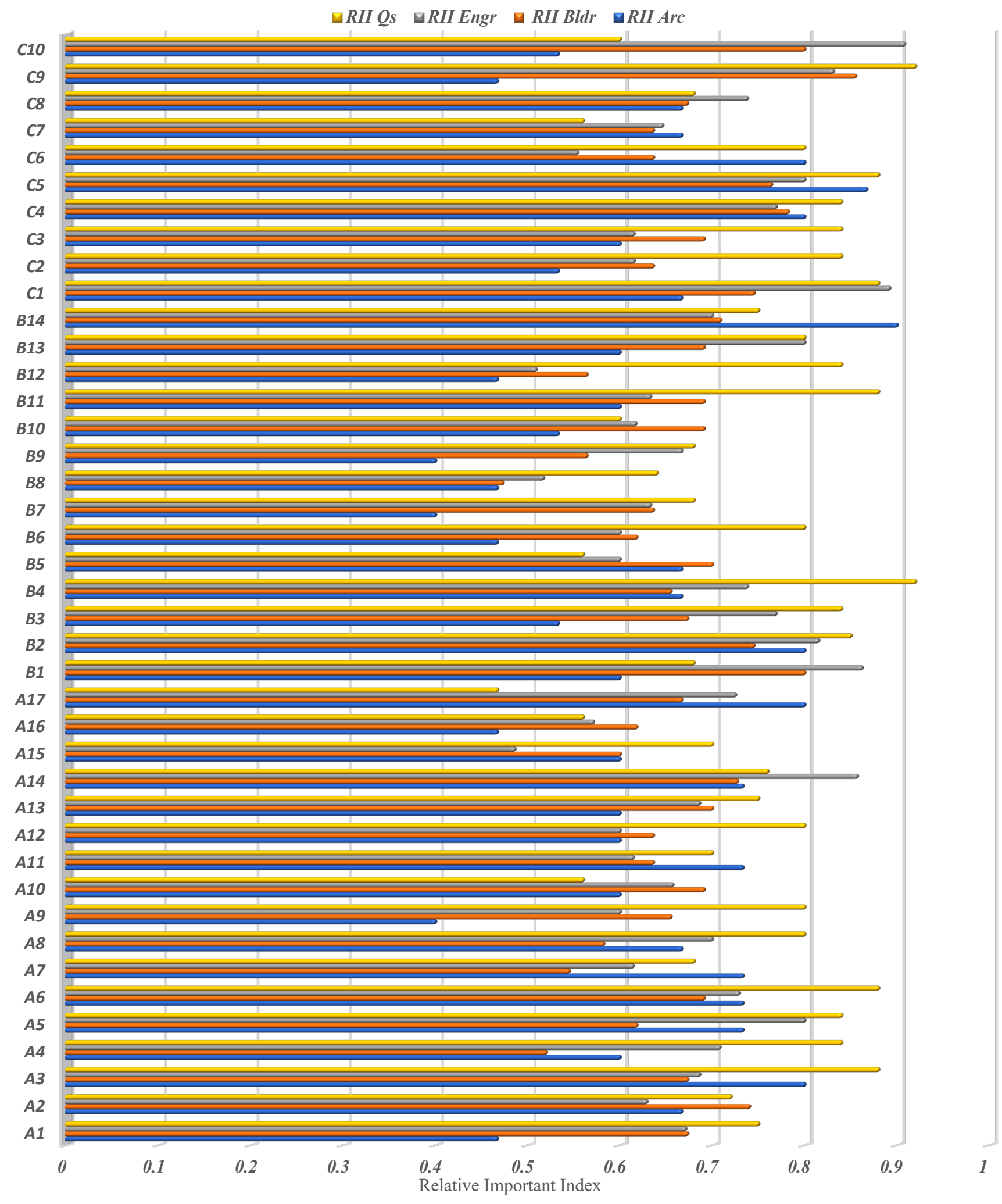


Fig. 4.2: Cluster diagram showing the Relative Importance Index (RII) of Large, Medium and Small companies

\author{
- SMALL MEDIUM - LARGE
}

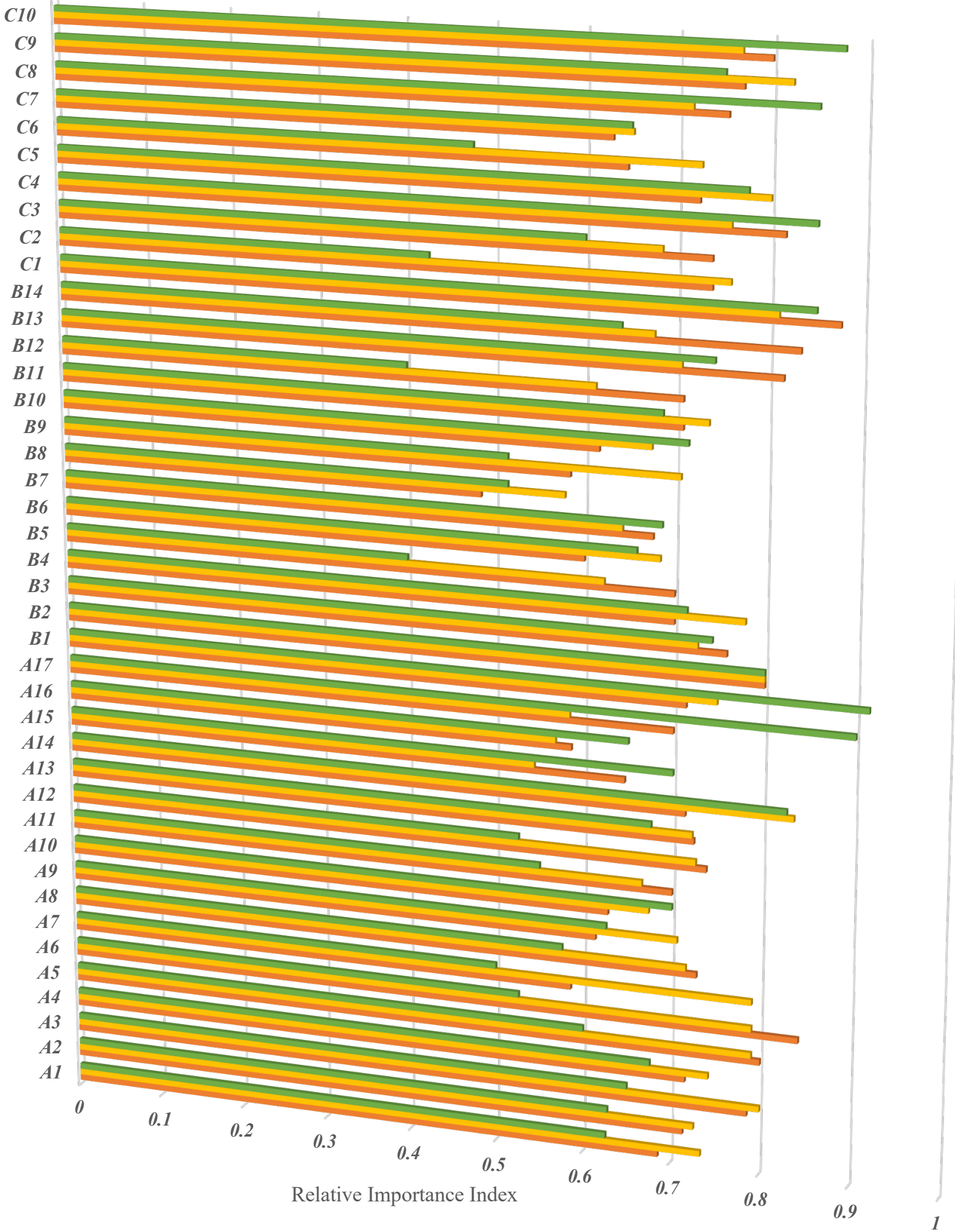


Table 4.10: Ranking for group of factors

\begin{tabular}{clcc}
\hline $\begin{array}{c}\text { Group } \\
\text { Code }\end{array}$ & Group & $\begin{array}{c}\text { Average } \\
\text { RII }\end{array}$ & Rank \\
\hline C & External Factor & 0.741 & 1 \\
A & Site Factors & 0.692 & 2 \\
B & Human Labour Factors & 0.684 & 3 \\
\hline
\end{tabular}

Table 4.10 shows that external factors, site and human factors ranked first, second and third. This indicates that enviroment of work and external factors have more affect on productivity than human labour factors.
Table 4.11 shows the difference in perception between Architect, Builders, Engineers and Quantity Surveyors. The Kruskal Wallis test showed that there was significant difference in perception of the various professionals of thirty-eight factors with $\mathrm{p}$-value ranging from 0.062 to 0.902 . However, no significant difference was observed for three factors. These factors are rain, economic crises and labour personal problems.

Table 4.11: Kruskal Wallis Test Results

\begin{tabular}{|c|c|c|c|}
\hline Factors & Kruskal-Wallis H & Asymp. Sig. & $\begin{array}{c}\text { Difference in } \\
\text { perception }\end{array}$ \\
\hline Delay in responding to request for information & 3.646 & 0.302 & Significant \\
\hline Rework & 3.722 & 0.293 & Significant \\
\hline Amount of variation/change of orders during execution & 3.168 & 0.366 & Significant \\
\hline Clarity of technical specification & 2.490 & 0.477 & Significant \\
\hline $\begin{array}{l}\text { Level of co-ordination among design disciplines i.e. Architects, } \\
\text { Engineers, etc. }\end{array}$ & 2.521 & 0.471 & Significant \\
\hline Compatibility and consistency among contract document & 3.978 & 0.264 & Significant \\
\hline $\begin{array}{l}\text { Strict inspection by the engineer } \\
\text { Complexity of the design and project } \\
\text { Restricted access on site } \\
\text { Inspection delay by the engineer } \\
\text { Confinement of working space }\end{array}$ & $\begin{array}{l}1.892 \\
3.987 \\
4.429 \\
1.270 \\
1.137\end{array}$ & $\begin{array}{l}0.595 \\
0.263 \\
0.219 \\
0.736 \\
0.768\end{array}$ & $\begin{array}{l}\text { Significant } \\
\text { Significant } \\
\text { Significant } \\
\text { Significant } \\
\text { Significant }\end{array}$ \\
\hline Site layout & 3.068 & 0.381 & Significant \\
\hline Mobilization/Demobilization & 1.059 & 0.787 & Significant \\
\hline Hazardous Work Area & 4.051 & 0.256 & Significant \\
\hline Excessive labour/Over-manning & 5.103 & 0.164 & Significant \\
\hline Lack of places for eating and relaxation & 1.418 & 0.701 & Significant \\
\hline Non provision of transport means for workers & 3.878 & 0.275 & Significant \\
\hline Shortage of experienced labour & 2.763 & 0.430 & Significant \\
\hline Skill of labour & 2.355 & 0.502 & Significant \\
\hline Lack of competition /motivation of labour & 5.770 & 0.123 & Significant \\
\hline Physical fatigue & 6.472 & 0.091 & Significant \\
\hline Craft workers' pride in their work & 0.894 & 0.827 & Significant \\
\hline Labour disloyalty & 4.139 & 0.247 & Significant \\
\hline Labour dissatisfaction & 3.139 & 0.371 & Significant \\
\hline Increase of labourer's age & 1.575 & 0.665 & Significant \\
\hline Drug abuse and alcoholism & 2.796 & 0.424 & Significant \\
\hline Labour absenteeism & 1.270 & 0.736 & Significant \\
\hline Poor health of workers & 4.231 & 0.238 & Significant \\
\hline Labour personal problems & 8.177 & 0.042 & Not Significant \\
\hline Poor economic condition of workers & 2.951 & 0.399 & Significant \\
\hline Literacy level & 2.918 & 0.404 & Significant \\
\hline Rain & 8.578 & 0.035 & Not Significant \\
\hline High Temperature & 4.183 & 0.242 & Significant \\
\hline Weather and Season Changes & 4.946 & 0.176 & Significant \\
\hline Government polices & 0.354 & 0.950 & Significant \\
\hline Cultural conditions and customs of the community at the project site & 2.548 & 0.467 & Significant \\
\hline Religious holidays/other holidays & 4.734 & 0.192 & Significant \\
\hline Rise in fuel prices & 0.575 & 0.902 & Significant \\
\hline Environmental pollution & 0.811 & 0.847 & Significant \\
\hline Conflict with project stakeholders & 7.319 & 0.062 & Significant \\
\hline Financial Crisis & 14.114 & 0.003 & Not Significant \\
\hline
\end{tabular}


Adagba et al. / Journal of Civil Engineering Frontiers Vol. 02, No. 02, pp. 26 -37, (2021)

\begin{tabular}{|c|c|c|c|c|c|c|}
\hline \multirow[t]{2}{*}{ Authors } & \multirow[t]{2}{*}{ Region } & \multicolumn{5}{|c|}{ Ranking of factors in various studies } \\
\hline & & 1 & 2 & 3 & 4 & 5 \\
\hline Current Research & $\begin{array}{l}\text { Zaria, } \\
\text { Nigeria }\end{array}$ & Rain & $\begin{array}{l}\text { Conflict with } \\
\text { project stakeholders }\end{array}$ & Skill of labour & Financial Crisis & Government policies \\
\hline Odesola, et al. [22] & $\begin{array}{l}\text { Bayelsa, } \\
\text { Nigeria }\end{array}$ & $\begin{array}{l}\text { Specifications } \\
\text { and standards }\end{array}$ & $\begin{array}{l}\text { Material } \\
\text { availability }\end{array}$ & Project goals & $\begin{array}{l}\text { High quality } \\
\text { requirement }\end{array}$ & $\begin{array}{l}\text { Non-availability of } \\
\text { drawings }\end{array}$ \\
\hline $\begin{array}{l}\text { Edwin and Calistus } \\
{[23]}\end{array}$ & $\begin{array}{l}\text { North- } \\
\text { central } \\
\text { Nigeria }\end{array}$ & Designs & $\begin{array}{l}\text { Change of drawings } \\
\text { and specification }\end{array}$ & $\begin{array}{l}\text { Working at high } \\
\text { places }\end{array}$ & Inexperience & Low wages \\
\hline $\begin{array}{l}\text { Olomolaiye, et al. } \\
\text { [1] }\end{array}$ & Nigeria & $\begin{array}{l}\text { Low material } \\
\text { supply }\end{array}$ & No working tools & Work repetition & $\begin{array}{l}\text { Delays in giving } \\
\text { instructions }\end{array}$ & Delays in inspections \\
\hline $\begin{array}{l}\text { Odesola and Idoro } \\
{[25]}\end{array}$ & $\begin{array}{l}\text { South- } \\
\text { South } \\
\text { Nigeria }\end{array}$ & $\begin{array}{l}\text { Craft workers' } \\
\text { pride }\end{array}$ & Lack of skills & Repetition of work & $\begin{array}{l}\text { Incompetent } \\
\text { supervisors }\end{array}$ & $\begin{array}{l}\text { Individual } \\
\text { problems/workers poor } \\
\text { condition }\end{array}$ \\
\hline $\begin{array}{l}\text { Jarkas and Bitar } \\
{[28]}\end{array}$ & Kuwait & $\begin{array}{l}\text { Non-clarity of } \\
\text { Specifications }\end{array}$ & $\begin{array}{l}\text { Variation/change of } \\
\text { orders }\end{array}$ & $\begin{array}{l}\text { Non-Coordination } \\
\text { among } \\
\text { Professionals }\end{array}$ & $\begin{array}{l}\text { Non-Supervision of } \\
\text { labour }\end{array}$ & $\begin{array}{l}\text { Work proportion } \\
\text { subcontracted }\end{array}$ \\
\hline $\begin{array}{l}\text { Makulsawatudom } \\
\text { and Emsley [29] }\end{array}$ & Thailand & $\begin{array}{l}\text { Low material } \\
\text { Supply }\end{array}$ & Incomplete drawing & $\begin{array}{l}\text { Delay in carrying } \\
\text { out inspections }\end{array}$ & $\begin{array}{l}\text { Non-competent } \\
\text { supervisors }\end{array}$ & $\begin{array}{l}\text { Time for issuing } \\
\text { instructions }\end{array}$ \\
\hline $\begin{array}{l}\text { Hickson and Ellis } \\
{[30]}\end{array}$ & $\begin{array}{l}\text { Trinidad } \\
\text { and } \\
\text { Tobago }\end{array}$ & $\begin{array}{l}\text { No supervision of } \\
\text { labour }\end{array}$ & $\begin{array}{l}\text { Unrealistic labour } \\
\text { performance } \\
\text { expectation }\end{array}$ & $\begin{array}{l}\text { Lack of qualified } \\
\text { labour }\end{array}$ & No leadership & Labourer's skill \\
\hline Gundecha [31] & USA & $\begin{array}{l}\text { Lack of material } \\
\text { needed for } \\
\text { construction }\end{array}$ & $\begin{array}{l}\text { Lack of basic } \\
\text { utilities }\end{array}$ & Accidents on site & Lack of tools & $\begin{array}{l}\text { Unfavourable } \\
\text { conditions on site }\end{array}$ \\
\hline $\begin{array}{l}\text { Khaled and Remon } \\
\text { [3] }\end{array}$ & Egypt & Labourer's skill & Lack of Incentive & $\begin{array}{l}\text { Material } \\
\text { availability \& } \\
\text { handling }\end{array}$ & $\begin{array}{l}\text { Incompetent site } \\
\text { managers }\end{array}$ & Labour supervision \\
\hline $\begin{array}{l}\text { Enshassi, et al. } \\
{[26]}\end{array}$ & Gaza & $\begin{array}{l}\text { Material } \\
\text { shortages }\end{array}$ & $\begin{array}{l}\text { Labourer's } \\
\text { experience }\end{array}$ & $\begin{array}{l}\text { No labour } \\
\text { surveillance }\end{array}$ & $\begin{array}{l}\text { Misunderstanding } \\
\text { between } \\
\text { superintendents and } \\
\text { labourers }\end{array}$ & $\begin{array}{l}\text { Drawings alteration } \\
\text { during project } \\
\text { execution }\end{array}$ \\
\hline $\begin{array}{l}\text { Thomas and } \\
\text { Sudhakumar [27] }\end{array}$ & India. & $\begin{array}{l}\text { Non-availability } \\
\text { of material on } \\
\text { time }\end{array}$ & $\begin{array}{l}\text { Delay in the supply } \\
\text { of material }\end{array}$ & Strikes & $\begin{array}{l}\text { Frequent drawing } \\
\text { revisions }\end{array}$ & $\begin{array}{l}\text { Timely availability of } \\
\text { drawings at the site }\end{array}$ \\
\hline Dixit, et al. [5] & India & $\begin{array}{l}\text { Making } \\
\text { Decisions }\end{array}$ & Planning & Logistics & $\begin{array}{l}\text { Availability of } \\
\text { Labour }\end{array}$ & Budgetary Issues \\
\hline $\begin{array}{l}\text { Durdyev and } \\
\text { Mbachu [32] }\end{array}$ & Cambodia & Leadership & Planning & $\begin{array}{l}\text { Inadequate } \\
\text { construction } \\
\text { methods }\end{array}$ & $\begin{array}{l}\text { Poor supervision of } \\
\text { labour }\end{array}$ & $\begin{array}{l}\text { Lack of effective } \\
\text { communication }\end{array}$ \\
\hline Afolabi [33] & Nigeria & $\begin{array}{l}\text { Availability of } \\
\text { material }\end{array}$ & Poor supervision & Payment Methods & Site welfare & Weather \\
\hline Ohueri, et al. [34] & Malaysia & $\begin{array}{l}\text { Non Effective } \\
\text { supervision }\end{array}$ & Lack of Incentives & Training & $\begin{array}{l}\text { Unsafe site } \\
\text { conditions }\end{array}$ & Career Progress \\
\hline Momade, et al. [35] & Qatar & Achievement & Recognition & Interesting work & $\begin{array}{l}\text { Decision making } \\
\text { involvement }\end{array}$ & Personnel development \\
\hline $\begin{array}{l}\text { Alaghbari, et al. } \\
{[36]}\end{array}$ & Yemen & Labourer's skill & $\begin{array}{l}\text { Material } \\
\text { availability }\end{array}$ & $\begin{array}{l}\text { Non-efficient } \\
\text { leadership and } \\
\text { management }\end{array}$ & $\begin{array}{l}\text { Material } \\
\text { availability in the } \\
\text { market }\end{array}$ & $\begin{array}{l}\text { Political/security } \\
\text { condition }\end{array}$ \\
\hline Palikhe, et al. [7] & Nepal & $\begin{array}{l}\text { Unavailability of } \\
\text { tools on site }\end{array}$ & $\begin{array}{l}\text { Untimely arrival of } \\
\text { material }\end{array}$ & $\begin{array}{l}\text { Delay in } \\
\text { procurement }\end{array}$ & No incentive & $\begin{array}{l}\text { Delay in payment for } \\
\text { materials }\end{array}$ \\
\hline $\begin{array}{l}\text { Shoar and Banaitis } \\
{[6]}\end{array}$ & Lithuania & $\begin{array}{l}\text { Unachievable } \\
\text { schedule }\end{array}$ & $\begin{array}{l}\text { High number of } \\
\text { labour }\end{array}$ & Rework & $\begin{array}{l}\text { Delays in payment } \\
\text { of wages. }\end{array}$ & Overtime \\
\hline Parath [37] & India & $\begin{array}{l}\text { No clear job } \\
\text { description }\end{array}$ & Planning & Worker's skill & $\begin{array}{l}\text { No adequate } \\
\text { Supervision }\end{array}$ & Coordination \\
\hline Bekr [4] & Jordan & Proper planning & $\begin{array}{l}\text { Shortage of } \\
\text { materials }\end{array}$ & $\begin{array}{l}\text { Shortage of } \\
\text { equipment }\end{array}$ & $\begin{array}{l}\text { Non-availability of } \\
\text { adequate labour }\end{array}$ & $\begin{array}{l}\text { Inefficient } \\
\text { management of sites }\end{array}$ \\
\hline Minde [38] & $\begin{array}{l}\text { Mumbai, } \\
\text { India }\end{array}$ & $\begin{array}{l}\text { Skills of the } \\
\text { labourer }\end{array}$ & $\begin{array}{l}\text { Material } \\
\text { availability. }\end{array}$ & $\begin{array}{l}\text { Methods of } \\
\text { construction }\end{array}$ & Site Safety & Work schedule. \\
\hline
\end{tabular}

Results represented on table 4.12 indicates that the factors influencing construction productivity depends on the geographical locations. Climatic conditions, method of construction, material use, availability and technological application as well as contractual procedures are some of the causative agents Gundecha [31].
However, a common factor across most regions and countries is the skill of labour. It ranks third in this research, second in south-south Nigeria, fifth in Trinidad and Tobago, and first in Egypt. 


\section{CONCLUSION AND RECOMMENDATIONS}

An assessment of factors in the construction industry influencing labour productivity in Zaria, Northwestern Nigeria was carried out. The following findings were obtained from the survey.

- $\quad$ The research shows that productivity of labour in the area considered is seriously affected as thirty-nine of the fortyone identified factors indicated high severity.

- Rain, conflict with project stakeholders, and skill of labour ranked first, second and third respectively in the level of severity.

- $\quad$ Architects, Builders, Engineers and Quantity Surveyors all have different perception on the factors affecting construction except for rain, financial crisis and labour personal problems.

- $\quad$ Architects viewed literacy level to be the most important factor, Builders viewed conflict with project stakeholders, Engineers viewed financial crisis to be the most important factor, while Quantity Surveyors viewed physical fatigue to be the most important factor.

- $\quad$ There exists a difference in significance of the factors across the regions and countries except for labourer's skill that ranked third in this research, second in south-south Nigeria, fifth in Trinidad and Tobago, and first in Egypt.

- External factors tend to affect construction labour productivity more than site and human labour factors. This is mostly due to the fact that site and human labour factors can be controlled to some extent by the site engineers but external factors can't really be controlled by the site engineers.

Professionals, especially those managing construction sites should pay more attention to controlling these factors to enhance more productivity on their sites. It is suggested that further studies be carried out on the level of influence these factors have on the productivity of labour.

\section{REFERENCES}

[1] P. O. Olomolaiye, K. A. Wahab, and A. D. F. Price, "Problems Influencing Craftsmen's Productivity in Nigeria," Building and Environment, vol. Vol. 22, No. 4, no. 317-323, 1987.

[2] A. A. Attar, A. K. Gupta, and B. D. Desai, "A Study of Various Factors Affecting Labour Productivity and Methods to Improve it," IOSR Journal of Mechanical and Civil Engineering, pp. 11-14, 2012.

[3] M. E. Khaled and F. A. Remon, "Factors Influencing Construction Labor Productivity in Egypt," Journal of Management in Engineering, 2013.

[4] G. Bekr, "Study of Significant Factors Affecting Labor Productivity at Construction Sites in Jordan: Site Survey," Journal of Engineering Technology (JET), vol. Volume 4, pp. 92-97, 07/01 2016, doi: 10.5176/2251-3701 4.1.178.

[5] S. Dixit, S. Mandal, J. Thanikal, and K. Saurabh, "Evolution of studies in construction productivity: A systematic literature review (2006-2017)," Ain Shams
Engineering Journal, vol. 10, 02/01 2019, doi: 10.1016/j.asej.2018.10.010.

[6] S. Shoar and A. Banaitis, "Application of fuzzy fault tree analysis to identify factors influencing construction labor productivity: A high-rise building case study," Journal of Civil Engineering and Management, vol. 25, pp. 41-52, 01/25 2019, doi: 10.3846/jcem.2019.7785.

[7] S. Palikhe, S. Kim, and J. Kim, "Critical Success Factors and Dynamic Modeling of Construction Labour Productivity," International Journal of Civil Engineering, vol. 17, 01/16 2018, doi: 10.1007/s40999-018-0282-3.

[8] A. Seddeeq, S. Assaf, A. Abdallah, and M. Hassanain, "Time and Cost Overrun in the Saudi Arabian Oil and Gas Construction Industry," Buildings, vol. 9, p. 41, 02/08 2019, doi: 10.3390/buildings9020041.

[9] A. Agarwal and S. Halder, "Identifying factors affecting construction labour productivity in India and measures to improve productivity," Asian Journal of Civil Engineering, vol. 21, 06/01 2020, doi: 10.1007/s42107-019-00212-3.

[10] S. M. Hafez, R. F. Aziz, E. S. Morgan, M. M. Abdullah, and E. K. Ahmed, "Critical factors affecting construction labour productivity in Egypt," Am J Chem Eng, vol. 2(2), pp. 35-50, 2014.

[11] S. Dantata, "General Overview of the Nigerian Construction Industry," Master of Engineering In Civil and Environmental Engineering, Department of Civil \& Environmental Engineering, Massachusetts Institute of Technology, 2007.

[12] NBS, "Nigerian construction Sector " in "Summary Report: 2010-2012," January 20152015.

[13] S. Abdullahi, "Determination Of Labour Outputs For Roof Carcassing, Roof Covering And Painting In The Nigerian Construction Industry," Ahmadu Bello University, Unpublished BSc. Project, Sepember 2010, 2010.

[14] K. Amadeo, "The Balance," in The Balance Web site, ed, 2018.

[15] C. Smriti. "Labour: Meaning and Characteristics." http://www.yourarticlelibrary.com/economics/labour -meaning-and-characteristics-economics/10795 (accessed July 22nd.

[16] Y. Kale and S. I. Doguwa, "On the Compilation of Labour Force Statistics for Nigeria," CBN Journal of Applied Statistics, vol. Vol. 6, No. 1(a), pp. 183-198, 2015.

[17] C. Paul and V. Bernard, "Measuring productivity in the construction industry," Building Research and Information, vol. 34(3), pp. 208-219, 2006.

[18] E. W. Merrow, K. A. Sonnhalter, R. Somanchi, and A. F. Griffith, "Productivity in the UK Engineering Construction Industry," Independent Project Analysis, 2009. University of New South Wales, , 2015. 
[20] J. W. Kendrick, "Productivity trends: capital and labour," Review of Economics and Statistics, vol. 38, p. 3, 1956.

[21] C. Ewe, LIM, The analysis of productivity in building construction. Loughborough: E.C. Lim, 1996.

[22] I. A. Odesola, M. Otali, and D. I. Ikediashi, "Effects of Project-Related Factors On Construction Labour Productivity in Bayelsa State of Nigeria," Ethiopian Journal of Environmental Studies and Management, vol. Vol. 6, pp. 817-826, 2013.

[23] A. A. Edwin and A. Calistus, "Critical factors influencing construction labour productivity in carpentry and steel fixing in North-Central Nigeria," International Journal of Development and Sustainability, vol. Vol. 4 no. 8, pp. 1675-1684, 2014.

[24] I. A. Odesola, "Assessment of Management-Related Factors Affecting Construction Labour Productivity in Cross River State of Nigeria," Covenant Journal of Research in the Built Environment, vol. Vol. 3, No. 2., pp. 13-29, 2015.

[25] I. A. Odesola and G. I. Idoro, "Influence of LabourRelated Factors on Construction Labour Productivity in the South-South Geo-Political Zone of Nigeria," Journal of Construction in Developing Countries, vol. Vol. 19, 2014.

[26] A. Enshassi, S. Mohamed, Z. A. Mustafa, and P. E. Mayer, "Factors affecting labour productivity in building projects in the Gaza strip," Journal of Civil Engineering and Management, vol. Vol. XIII, pp. 245-254, 2007.

[27] V. A. Thomas and J. Sudhakumar, "Factors Influencing Construction Labour Productivity: An Indian Case Study," Journal of Construction in Developing Countries, vol. Vol. 19(1), pp. 53-68, 2014.

[28] M. A. Jarkas and G. C. Bitar, "Factors Affecting Construction Labor Productivity in Kuwait," Journal of Construction Engineering and Management, vol. Vol. 138, pp. 811-820, 2012.

[29] A. Makulsawatudom and M. Emsley, "Factors Affecting the Productivity of the Construction Industry In Thailand: The Project Managers' Perception," in 17th Annual ARCOM Conference, University of Salford, 2001, vol. Vol. 1.

[30] G. B. Hickson and L. A. Ellis, "Factors affecting Construction Labour Productivity in Trinidad and
Tobago," The Journal of the Association of Professional Engineers of Trinidad and Tobago, vol. Vol. 42, No. 1, pp. 4-11, 2014.

M. M. Gundecha, "Study of Factors Affecting Labour Productivity at a Building Construction Project in the USA: Web Survey," Master of Science, Construction Management and Engineering, North Dakota State University Of Agriculture and Applied Science, Fargo, North Dakota, 2012.

[32] S. Durdyev and J. Mbachu, "Key constraints to labour productivity in residential building projects: evidence from Cambodia," International Journal of Construction Management, vol. 18, pp. 1-9, 05/15 2017, doi: 10.1080/15623599.2017.1326301.

[33] A. O. O. Afolabi, R. A; Omuh, I; Tunji-Olayeni, P; Adeyemi, M, "Critical success factors influencing productivity of construction artisans in the building industry.," International Journal of Mechanical Engineering and Technology (IJMET), vol. Volume 9, no. Issue 8, pp. 858-867, 2018.

[34] C. Ohueri, W. Enegbuma, N. Wong, K. Kuok, and R. Kenley, "Labour productivity motivation framework for Iskandar Malaysia," Built Environment Project and Asset Management, vol. 8, 05/24 2018, doi: 10.1108/BEPAM-09-2017-0070.

[35] M. H. Momade, S. Shahid, M. R. Hainin, and M. Nashwan, "Construction Labour Productivity: Review of Factors Identified," International Journal of Construction Management, 06/12 2019, doi: 10.1080/15623599.2019.1627503.

[36] W. Alaghbari, A. Al-Sakkaf, and B. Sultan, "Factors affecting construction labour productivity in Yemen," International Journal of Construction Management, vol. 19, pp. 79-91, 10/11 2019, doi: 10.1080/15623599.2017.1382091.

[37] V. Parath, "Improvement of Manpower and Equipment Productivity in Indian Construction Projects," 01/01 2019.

[38] P. R. G. A. B. M. P. R. Minde, "Importance of measurement of labour productivity in construction," IJRET: International Journal of Research in Engineering and Technology, 2016. 